\title{
Time Preference and Natural Resource Use by Local Communities: The Case of Sinharaja Forest in Sri Lanka
}

\author{
H.M. Gunatilake, W.A.R. Wickramasinghe and \\ P. Abeygunawardena *
}

\begin{abstract}
This paper investigates the impact of individual rate of time preference (IRTP) on forest resources harvesting from the Sinharaja forest in Sri Lanka. The impact of IRTP on the harvest rate of forest resources was tested using a simultaneous equation model. Analyses show that low income results in a higher IRTP, indicating that poverty is an important determinant of the IRTP. Further, the results show that individuals with a higher rate of time preference harvest more forest resources. Overall, the results suggest that long-term strategies for management of nature reserves would require poverty alleviation in the peripheral communities, among other measures.
\end{abstract}

\section{Introduction}

An individual's preference for current over future consumption, called the rate of time preference or the rate of discount, ${ }^{1}$ is an important topic in economics. The generally held perception is that a higher rate of time preference typically accelerates natural resource harvesting and depresses investment for sustainable natural resource management. Higher discount rates $^{2}$ also reduce the weights attached to the needs and desires of future

\footnotetext{
The authors are, respectively, Senior Economist, Economic Analysis and Operations Support Division, Economics and Research Department, Asian Development Bank, Graduate Student, Amsterdam Institute for Metropolitan and International Development Studies, University of Amsterdam, The Netherlands and Professor and Associate Director, International Program, Texas A\&M University, USA. Corresponding author's email: hgunatilake@adb.org

1 Time preference is defined as the marginal rate of substitution between current and future consumption (Becker and Mulligan 1997). We use the terms "rate of time preference" and "discount rate" interchangeably, as did Poulos and Whittington (2000), Godoy et al., (1998), Becker and Mulligan (1997), and Olson and Bailey (1981).

2 In day-to-day decisions, people apply their time preference. In order to reflect this practice of use of time preference, future costs and benefits are discounted in project analysis. The social discount rate is also influenced by the opportunity
} 
generations. Therefore, a higher rate of time preference is viewed as a cause of depletion of natural resources and an obstacle to conservation. With this perception in mind, many environmentalists have suggested the use of lower discount rates for evaluation of natural resources and environmental projects.

This idea of using lower discount rates in natural resources and environmental projects is not new. Discussions on adjustment of the discount rate for conservation of the stock of natural capital, both in exhaustible and renewable resources, have persisted since the 1930s (Fisher and Krutilla 1995). Pigou (1932) may be the first to point out the need to use lower discount rates in the case of management of exhaustible resources (quoted in Fisher and Krutilla 1995). Early writings in natural resource economics consistently showed that a higher rate of discount leads to excessive use of natural resources. For example, see discussions by Hotelling (1931) for exhaustible resources and Clark (1973) for renewable resources. In recent times, there has been renewed interest in the argument for using a lower discount rate. For example, Weitzman (1994) argues for lower and declining discount rates for long-term benefit-cost analysis, for a variety of economic reasons. He further argues (Weitzman 1998) for the lowest possible discount rate for discounting the distant future. More recently, the use of a low discount rate in the Stern Report (Stern 2006) to estimate the cost of climate change has stimulated a heated debate on the impact of discounting on natural resources and the environment.

Despite its persistence for a long time the claim that a lower discount rate is desirable for natural resource conservation has not been universally accepted by economists. For example, Fisher and Krutilla (1995) argue that an arbitrary reduction of the social discount rate is likely to result in more rapid extraction and wasteful use of natural resources. The mass balance principle described by Ayres and Kneese (1969), also shows that high discount rates discourage more natural resources use than low discount rates do. Farzin (1984) shows that the discount rate has an ambiguous effect on the depletion period of an exhaustible resource under two situations: (i) backstop price is a function of the rate of time preference; and (ii) production is capital-intensive. Bulte and van Soest (1996) explain that under the circumstance of restricted supply (due to existence of timber concession contracts), depleting the primary stock of forests implies building a stock of secondary forests. When this happens, as they argue, the impact of the rate of time preference on the primary forest stock is ambiguous. Price (1991) also claims that lowering the discount rate may actually promote short-term exploitation of forests.

cost of capital. See Zhuang et al., (2007) for a good discussion on the theory and practice of discounting. 
Most of the above claims on the impact of time preference on natural resource use are based on theoretical models/arguments. When theory does not show clear direction of a relationship, empirical work may play an important role. However, empirical work that verifies the relationship between time preference and rate of natural resources use is limited. This lack of empirical tests on the impact of the rate of time preference on natural resource harvesting is more significant in developing countries where some of the important resources such as tropical rain forests are found. It is also important to note that most of the people living near such resources are either poor or extremely poor. Their survival often depends on continuous availability of such resources. In this study, we examine the relationship between individual rate of time preference (IRTP) and the harvest of forest resources by local communities.

Among the few empirical studies that attempted to estimate IRTP in developing countries, Poulos and Whittington (2000) use data on mortality reduction in Africa, Eastern Europe, and Asia. Holden et al., (1998) measure IRTP in Indonesia, Zambia, and Ethiopia using a stated preference survey. Reddy (1995) estimates IRTP using durable energy carrier choices in urban Indian households. Pender (1996) estimates the IRTP of rural villagers in southern India and relates this to credit markets. While these studies have estimated IRTP for various purposes in developing countries, the work of Godoy et al., (1998) is the only study that we know of that has estimated IRTP in developing countries in relation to forest resource use. Godoy et al., (1998) estimate the IRTP of peripheral villagers of Bolivian rainforests and relate it to the clearance of old growth forests. Their findings suggest that a higher IRTP is associated with less deforestation, which is contrary to common perception. Against this background, the objective of the present study is to test whether an individual with a higher rate of time preference harvests more forest resources, specifically, non-timber forest products (NTFP). Our findings show that individuals with a higher rate of time preference harvest more forest resources.

The rest of the paper is organized as follows. The second section discusses the importance of NTFP in managing protected rain forests and their contributions to poverty reduction. The third section describes the use of the survey method in eliciting the IRTP in the case study area of the Sinharaja forest. The fourth section presents the details of model specification and hypotheses of the study. The fifth section describes the study area, sampling, and data collection. Section six discusses the results of the study, and the final section presents conclusions and policy implications.

\section{Non-timber Forest Products Harvesting and Forest Conservation}


Non-timber forest products include a variety of products such as food (fruits, vegetables, yams, green leaves); game animals; medicinal plants; and raw materials for cottage industries (such as bamboo, rattan, resins, sugary saps). In the past, forest managers focused only on managing timber resources and, in effect, ignored the other forest products used by local communities. Work by Peters et al., (1989), de Beer and McDermott (1989), Panayotou and Ashton (1992), Godoy et al., (1993), and Gunatilake (1995), among other studies, showed the significance of NTFP in sustaining rural livelihoods and their potential role in the protection/destruction of biological diversity.

Loss of biodiversity is a cause for global concern. The major policy response of developing countries to this growing concern has been to designate more lands as protected areas (Ghimire, 1994). There are more than 8,500 protected areas in the world today, which cover about 800 million hectares of land. A large portion of these protected areas is located in developing countries. Although developing countries have allocated forest land for protection, often due to various pressures from local and international interest groups, management of these sites has not been successful. One of the major problems faced in the management of protected areas in developing countries is resource use by local communities (Gunatilake, 1998). For example, resource use by local communities is a major cause of the loss of closed canopy forests in Asia, rather than the commercial extraction of timber, as traditionally perceived (World Bank, 1993).

Clearance of forest lands for agriculture by local communities accounts for part of the destruction of natural forests. Once the boundary of a protected forest is well established, forest clearing for agriculture becomes less feasible while NTFP extraction may continue (Gunatilake and Chakravorty, 2002). Forest resource use by local communities is important due to a number of reasons. First, local communities have the closest physical contact with forests and have been using forest resources for generations. Second, local communities are adversely affected by resource use restrictions imposed by conservation projects (Gunatilake et al., 1993; Wells, 1992; Panayotou, 1994; Gunatilake, 1995 and 1998; Shyamsundar and Kramer, 1996). Third, local communities extract most of the NTFPs for their survival rather than for commercial uses. Fourth, there is a mismatch between what is considered as benefits from conservation by local communities and by conservationists. Finally, local communities may have little or no incentive for conservation because the benefits of rainforest conservation largely flow to national and global levels due to associated externalities (Tisdell, 1995). Therefore, better understanding of the interactions between protected forests and rural communities living around them is crucial for the successful implementation of conservation projects. 
Harvesting forest resources by local communities, as generally perceived, may be ecologically less destructive compared to clear felling of a forest for timber. However, there is continuing debate on the conditions necessary for sustainable harvest of non-timber forest resources and the extent to which such NTFP use affects conservation (Wells, 1992; Homma, 1992; Hanson, 1992; Browder, 1992; Godoy et al., 1995; Simpson, 1995). Most of the assertions on the impact of forest resource use by local communities on biological diversity in the present debate are derived from logical arguments and historical reviews. Gunatilake (1998) argues for reduction of the dependency on NTFP as a conservation strategy. Given scientific uncertainties, practical difficulties, and the high cost of ecological monitoring required to ensure the sustainable use of NTFP by local communities, he proposes the reduction of dependency through rural development activities. This is seen as a more pragmatic and cost-effective approach to forest protection.

\section{Estimation of Individual Rate of Time Preference}

In this paper, we estimate the IRTP using a stated preference survey among the peripheral villagers of the Sinharaja Man and Biosphere Reserve in Sri Lanka. We use a simple discounted utility model that is commonly used as the theoretical framework in estimating the IRTP. This model is adopted from Olson and Bailey (1981) and Poulos and Whittington (2000) and modified slightly to represent the study context.

\section{A. Estimating the Individual Rate of Time Preference}

Consider a representative villager living in the periphery of a protected forest. Assume that the individual's utility function has one argument, which represents a composite commodity C.

$$
U=\sum_{t=0}^{T} w_{t} U\left(C_{t}\right)
$$

where $\mathrm{T}$ is the planning horizon of the individual, wt is the discount factor, and $\mathrm{Ct}$ is the consumption at time $t$. We assume that utility is increasing at a decreasing rate with $\mathrm{C}$, lifetime utility is additively separable, and the utility function is stable over time. The discount factor is a function of pure time preference $r$ and time $t$.

Consider two distinct time periods, 0 and T. Assume that the consumption level for all the periods except for time 0 and $\mathrm{T}$ are constant. At 
the individual's point of indifference between marginal changes in consumption on the periods 0 and $\mathrm{T}$

$$
\begin{aligned}
& d U=U^{\prime}\left(C_{0}\right) d C_{0}+f(r, T) U^{\prime}\left(C_{T}\right) d C_{T}=0 \\
& \left|\frac{d C_{0}}{d C_{T}}\right|_{U=\text { constant }}=-f(r, T) \cdot \frac{U^{\prime}\left(C_{T}\right)}{U^{\prime}\left(C_{0}\right)}
\end{aligned}
$$

The right hand side of equation (4) shows how the individual trades off current and future consumptions in order to keep his/her utility constant. The rate at which future and current utilities are traded is equal to the discount factor. The discount factor is a function of the pure rate of time preference, $r$, and the inter-temporal marginal rate of substitution. The second component represents diminishing marginal utility of future consumption arising due to future income increases (Olson and Bailey, 1981).

Define:

$$
\frac{1}{(1+r)^{\top}}=-f(r, T) \cdot \frac{U^{\prime}\left(G_{T}\right)}{U^{\prime}\left(C_{0}\right)}
$$

In order to adapt the above general case to NTFP harvesting, assume that the utility function only has the NTFP income as an argument. Assume a villager is faced with a choice of NTFP income in two time periods, 0 and T. We can rewrite the utility function more precisely as,

$$
U=U\left(I_{0}, I_{\mathrm{T}}\right)
$$

If the individual is indifferent between NTFP income levels I0 and IT, the choice can be represented as:

$$
U\left(I_{0}, 0\right)=f(r, T) \cdot U(0, F)
$$

Total differentiation of (7) provides:

$$
U^{\prime}\left(I_{0}\right) \cdot I_{0}+f(r, T) \cdot U^{\prime}\left(I_{\top}\right) \cdot I_{\top}=0
$$

Rearranging the above results in:

$$
\frac{I_{0}}{I_{T}}=-f(r, T) \cdot \frac{U^{\prime}\left(I_{r}\right)}{U^{\prime}\left(I_{0}\right)}
$$


Using the results of (5) and solving equation (9) for $r$ provides:

$$
r=\left[\frac{I_{I}}{I_{0}}\right]^{\frac{1}{T}}-1
$$

Equation (10) shows that the IRTP can be estimated, if one can find the future income level $\left(\mathrm{I}_{\mathrm{T}}\right)$ and current income $\left(\mathrm{I}_{0}\right)$ that can keep the individual's utility constant. Stated preference survey questions can be designed to elicit the indifference between a given current level of income and a future level of income.

\section{B. Elicitation Question}

Loewenstein and Prelec (1992) identify four anomalies that commonly occur in eliciting the IRTP using stated preference questions: common difference effect, absolute magnitude effect, gain-loss asymmetry, and delay speed-up asymmetry. Preference between the two consumption adjustments should depend on the absolute time interval separating them. This is known as the stationarity property. ${ }^{3}$ Violation of the stationarity property is known as the common difference effect. Empirical studies on IRTP show that large money values suffer less proportional discounting than do small amounts. This effect is known as the absolute magnitude effect. Another behavior observed in previous studies is that losses are discounted at a lower rate than gains. This anomaly is known as the gain-loss asymmetry. Finally, the preferences of the inter-temporal choices are asymmetric for speed-up or delaying consumption. When framing an elicitation question for IRTP, one needs to consider the above four anomalies.

In our study, we first conducted a survey on NTFP harvesting by household. While the survey was going on, the quantities of NTFP harvested were input into an Excel spreadsheet, which is programmed to provide the total value of NTFP. Then we asked the following elicitation question from the respondent:

The Forest Department (FD) has decided to completely stop NTFP collection in the Sinharaja forest for one year to allow recovery of the forest. FD will make a payment to each household in order to compensate for lost NTFP income during this year. The payment is equal to last-year's value of NTFP. If your last-year NTFP income is $\left(\mathrm{I}_{0}\right)$, you will receive this amount from FD for not collecting NTFP from Sinharaja during the next year.

3 Delaying consumption from year 1 to 5 should have the same impact as year 5 to 10 . However the empirical studies show different time preferences in these types of cases despite the fact that absolute differences are the same. 
However, due to administrative problems, the payment may be delayed. How much do you want the FD to pay you if the payment is made exactly after one year from the due date? $\left(\mathrm{I}_{\mathrm{T}}\right)$, is the question posed to the respondents.

The question was repeated with different delaying times (years 1, 2, $3,5,10$, and 15).

With this elicitation format, every individual gets a question with a different base value since NTFP income varies across households. These different base values allow us to isolate the impact of absolute magnitude effect by incorporating the base value as an explanatory variable in the equation for determinants of IRTP. Varying time delays are used in the elicitation format to account for the common difference effect. We estimated the IRTP for each individual for the above six different time delays and took the average value as the IRTP of that individual in our analysis on the impact of IRTP on NTFP harvesting. However, the other two anomalies identified by Loewenstein and Prelec (1992) were not addressed by our eliciting format.

One reason for our inability to account for gain-loss asymmetry is the difficulty involved in interpreting the above format as a gain or loss. Collection of NTFP is always subjected to some uncertainty and involves laborious work. Therefore, villagers may consider that payment made by the FD, equivalent to NTFP value, as a gain. On the other hand, people collect a variety of products from the forest and this variety adds diversity to their lives. Certain NTFP may not have substitutes in the market. In that case, the above format may be interpreted as a loss, rather than a gain. Moreover, the next year may provide more NTFP due to natural fluctuations. In that case, income based on this year's NTFP value may imply a loss. Despite this difficulty to interpret whether the above eliciting format represents a gain or a loss, we attempted a different format to represent a loss. In that format, the eliciting question was framed stating that the household should pay the value of collected NTFP to the FD to represent a loss. In the pre-testing stage we understood that the question was too sensitive and people did not accept the scenario that they should pay for the resources, which they have been using for generations. Pretesting indicated a large proportion of scenario rejection. Therefore, the elicitation format developed to represent loss of income was dropped.

Accounting for the speed/delay anomaly was also tried. However, it was felt that too many of these questions confuse the rural households. Respondent fatigue was observed during the pretesting with different formats in a sequence with the same respondent. Based on the focus group discussions and experience of pretesting, the above format was selected as the best eliciting format. One potential problem with our elicitation format is the 
hypothetical nature of the question. Many researchers such as Pender (1996), Holden et al., (1998), and Poulos and Whittington (2000) have estimated IRTP values in developing countries with hypothetical questions. In order to avoid the "hypothetical nature" problem, actual payments were made by some researchers (for example, Godoy et al., 1998, and Gunatilake and Chakravorty, 2002). We did not attempt to use actual payments because our budget was inadequate to make such payments. Moreover, in actual payment studies, time delays will have to be limited to a few days or weeks, for practical reasons. If time delays are limited to a few days or weeks, the researcher would not be able to account for the common difference effect.

\section{Hypotheses and Model Specification}

\section{A. Determinants of IRTP}

In this study we test two sets of hypotheses. The first set of hypotheses analyzes the determinants of IRTP. Table 1 presents the variables included in the IRTP equation and the expected relationships.

Table 1: $\quad$ Variables used in Time Preference Model

\begin{tabular}{lc}
\hline Variable & Expected Relationship \\
\hline Base value $\left(\mathrm{X}_{1}\right)$ & Negative \\
Respondent's education $\left(\mathrm{X}_{2}\right)$ & Negative \\
Total household income $\left(\mathrm{X}_{3}\right)$ & Negative \\
Respondent's age $\left(\mathrm{X}_{4}\right)$ & Negative \\
Risk perception $\left(\mathrm{X}_{5}\right)$ & Negative \\
\hline
\end{tabular}

(i) Base Value. As mentioned earlier, base value is included as an explanatory variable in order to account for the absolute magnitude effect. There is a tendency to discount future incomes at lower rates when the sums involved are large (Loewenstein and Prelec, 1992). The study by Benzion et al., (1989) also shows that the IRTP is inversely related with the base value. Therefore, we assume that the rate of time preference is negatively related with the base value.

(ii) Level of Education. Education facilitates people to imagine the future vividly. Educated people have a better appreciation of future utility or benefits. Moreover, the level of education is assumed to increase income and consequently reduce poverty. Therefore, education reduces impatience, leading to lower rates of time preference (Becker and Mulligan, 1997). It is hypothesized that IRTP is negatively related to the level of education. 
(iii) Household Income. It is claimed that people who have higher income levels possess a lower rate of time preference than those with lower income levels (Becker and Mulligan, 1997). Low-income groups are expected to be more impatient due to the great need for providing for current consumption as well as due to lack of selfcontrol and foresight. Hausman (1979), Reddy (1995), and Holden et al., (1998) show consistent empirical evidence on the negative relationship between income and IRTP. The Poulos and Whittington (2000) study, however, does not show a strong relationship between IRTP and income. In this study we hypothesize income to be inversely related to IRTP.

(iv) Age. The effect of age on the rate of time preference is ambiguous. It is argued that older people have a lower rate of time preference than younger people due to the impatience of the young. Counter arguments suggest that older people tend to consume more at present than in the future due to the uncertainty of living longer. However, the need for leaving bequests prevents the aged from possessing extremely high IRTP (Boardman et al., 1996). According to Becker and Mulligan (1997), the younger and the older have similar rates of time preference. In this study, we assume that the rate of time preference is inversely related with the age of the respondent.

(v) Risk Perception. When the people's existence, prevalence of similar preference for consumption in the future, and availability of benefits in the future are uncertain, people perceive that they would not be able to consume in the future. As a result, they tend to have a higher IRTP. According to Olson and Bailey (1981), uncertainty can affect positively or negatively the IRTP and it is to a large extent an empirical matter. They argue that risk aversion and absence of insurance markets for most goods may play a role in the determination of IRTP. Holden et al.'s results (1998) show that riskaverse people tend to have lower discount rates. In this study we assume that individuals' perception on risk and IRTP are directly related.

\section{B. Socioeconomic Determinants of NTFP Harvesting}

The second set of hypotheses analyzes the socioeconomic determinants of NTFP harvesting in which the IRTP is one argument. Gunatilake (1998) and Gunatilake and Chakravorty (2002) have studied the determinants of NTFP extraction previously in the same study area. Our main objective is to study the impact of IRTP on NTFP harvesting, rather than determinants of NTFP harvesting. However, analysis on the determinants of 
NTFP harvesting is repeated in this study in order to avoid specification errors due to omitted variables in the second equation. Table 2 provides a summary of the variables and anticipated relationships.

Table 2: $\quad$ Variables used in NTFP harvesting equation and expected relationships

\begin{tabular}{lc}
\hline Variable & Expected Relationship \\
\hline Rate of time preference $\left(\mathrm{Y}_{1}\right)$ & Positive \\
Level of education $\left(\mathrm{X}_{2}\right)$ & Negative \\
Agricultural income $\left(\mathrm{X}_{6}\right)$ & Negative \\
Other income $\left(\mathrm{X}_{7}\right)$ & Negative \\
Family size $\left(\mathrm{X}_{9}\right)$ & Positive \\
Distance to forest $\left(\mathrm{X}_{10}\right)$ & Negative \\
Male-female ratio $\left(\mathrm{X}_{11}\right)$ & Positive \\
Index for market incorporation $\left(\mathrm{X}_{12}\right)$ & Positive \\
\hline
\end{tabular}

(i) IRTP. It is claimed that the greater the rate of time preference, the higher is the rate of resource use. Persons with high rates of time preference are more impatient compared to those with low rates of time preference. The more impatient persons extract more resources at present relative to less impatient persons. Gunatilake and Chakravorty (2002) show, using a theoretical model, that villagers with a higher time preference harvest more NTFP. In this study, we assume a positive relationship between IRTP and quantity of NTFP harvested.

(ii) Level of Education. As pointed out by Anderson (1992), NTFP harvesting requires low levels of capital and also brings low economic returns. There is evidence indicating that higher wages in the rural community result in less dependency on forest resources (Bluffstone 1995; Dufoumaud et al., 1995; Kerkvliet and Nebesky 1997; Gopalakrishnan et al., 2005). Higher education enables earning higher wages. Moreover, individuals with high opportunity costs of labor show less interest in forest extraction relative to those with low opportunity costs. Therefore, level of education is assumed to be inversely related to the quantity of NTFP harvested.

(iii) Agricultural Income. Gunatilake and Chakravorty (2002), using a model of competitive time allocation between forestry and agriculture, show that higher agricultural prices lead to the harvesting of decreased quantities of NTFP. Agricultural income is a proxy for agricultural prices. Therefore, in this study we hypothesize that agricultural income is inversely related to NTFP harvesting. 
(iv) Nonagricultural and Non-forest Income. Assume that a household allocates its total available time among forest-gathering activities, agriculture, and other economic activities. The more time it allocates for other economic activities leaves less time available for forest resource harvesting and agriculture. In such a competitive time allocation framework, the dependency on the forest is assumed to decrease with the availability of income from other sources (Gunatilake and Gopalakrishnan, 2002). As people become rich with higher levels of other income, they tend to veer away from subsistence economic activities such as gathering NTFP and shifting cultivation (Godoy and Bawa, 1993; Gunatilake et al., 1993; Godoy et al., 1995). Moreover, working for non-agricultural and non-forest income occupies the people throughout the year, which leaves less or no time for forest-resource gathering activities (Gunatilake, 1998). Therefore, it is hypothesized that income other than from agriculture and forestry is inversely related to NTFP harvesting.

(v) Extent of Homestead. Homestead is supposed to be an alternative source for forest products because it has the potential of providing forest products such as fuel wood, greens, spices and some vegetables, yams, etc. Therefore, it is hypothesized that NTFP harvesting is inversely related to the extent of homestead.

(vi) Family Size. If a family has more members, it needs extra income to support extra subsistence requirements. On the other hand, larger families may have more labor available for forest resource gathering. Hence, larger families can allocate more labor for NTFP harvesting in order to fulfill additional requirements (Gunatilake and Gopalakrishnan, 2002). Accordingly, we hypothesize that NTFP harvesting is directly related to family size.

(vii) Distance to the Forest. Households residing close to the forest require less time to reach NTFP sources, compared to those residing far away. In previous studies, Gunatilake (1998) and Gunatilake and Chakravorty (2002) show a negative relationship between NTFP harvesting and distance to the forest. In this study, we also hypothesize that distance to the forest is inversely related to NTFP harvesting.

(viii) Male-Female Ratio. Composition of the NTFP varies from site to site. Depending on the tradition of division of labor and composition of NTFP, the male-female ratio can have a positive or negative relationship with NTFP gathering. In the Sinharaja area, males seem to be involved in many forest-based activities. Among the forest- 
based activities in the study area, males generally carry out Kithul ${ }^{4}$ tapping, trapping and hunting wild animals, collecting materials for weaving baskets, and collecting food items. Consequently, a family with more males is supposed to extract more forest products relative to a family with few males. Therefore, it is hypothesized that NTFP harvesting is directly related to the male-female ratio in a family.

(ix) Market Incorporation. Integration of remote villages with outside markets through better infrastructure may affect NTFP harvesting in different ways. One argument is that outside markets provide many opportunities for income-generating activities. Therefore, market incorporation reduces dependency on forest resources. Browder (1992) and Godoy and Bawa (1993) assert that people living far away from markets may deplete forest resources. A counter argument is that when rural communities are linked with outside markets, it provides avenues for harvesting NTFP for commercial purposes. Compared to subsistence uses, commercial uses may lead to the harvesting of more NTFP and lead to quicker forest resource depletion. In this study, we hypothesize that the rate of forest resource harvesting is directly related to the integration of rural communities with outside markets.

The above-described two sets of hypotheses were tested using two regression equations for IRTP and NTFP harvesting. The dependent variable in the IRTP equation is an independent variable in the NTFP equation. This may cause simultaneous bias if these equations are estimated as single equations. A closer look at the equations shows that they represent a recursive system. However, the simultaneity test (Hausman test) indicates the presence of simultaneous bias. Therefore, we estimated the equations as a system. We used order and rank conditions as described by Greene (2000) to identify the equation and our analysis shows that equations are over identified. Therefore, we used two-stage least squares method to estimate the equations simultaneously.

\section{Sampling, Data Collection, and Measurement of Variables}

The Sinharaja Man and Biosphere reserve is a lowland rainforest located in southern Sri Lanka. The biological richness of Sinharaja has drawn the attention of the national and international community. It was declared as a Man and Biosphere Reserve in 1978 by the United Nations Educational, Scientific and Children's Organization, which also recognized the Sinharaja as a World Heritage Site in 1988. The Sinharaja is the only remaining

4 The flower of the Kithul palm tree is tapped for its sugary sap. 
relatively large $(11,000$ hectares) and less disturbed lowland tropical rainforest in Sri Lanka. Nine of the 15 floristic regions in the country are located in the Sinharaja. Ninety-five percent of the endemic birds and $70 \%$ of the endemic woody plants are said to exist in the Sinharaja (Gunatilleke and Gunatilleke, 1980). There is a considerably large forest-dependent community living around the forest. McDermott et al., (1990) have identified 223 plant species, which are of some use to villagers. The biological richness and the long-lasting forestry-people interactions existing in the Sinharaja, thus make it an ideal site for empirical verification of the hypotheses described earlier in this paper.

The property right of a forest resource affects the IRTP of resource users. For example, Hardin's "tragedy of the commons" (1968) occurs in an open-access situation and that the implied IRTP in this situation is infinite (Pender, 1996). The government owns the Sinharaja forest and NTFP extraction was legally prohibited by early legislation. The Sri Lanka Forestry Sector Master Plan (Ministry of Forestry and Environment, 1995) recommended allowing local communities to use NTFP from protected forests in Sri Lanka. Since then the FD adopted a lenient attitude toward NTFP use by local communities, though it does not actively promote the use of NTFP in the Sinharaja. The FD issues permits for tapping Kithul trees in the forest. There are a number of non-governmental organizations working in the area promoting the marketing and processing of some NTFP and cottage industries using NTFP. Other projects involve enrichment planting of selected NTFP in the buffer zone of the forest with community participation. Given all these activities in the community, some form of community management regime for forest resources seems to be evolving. Therefore, a de facto open-access extractive reserve, often developed with government ownership, does not prevail in the Sinharaja forest.

The study was conducted in peripheral villages of five forest patches newly added to the Sinharaja protected area. They are Delwala and Walankanda forests in Ratnapura district, Runakanda forest in Kalutara district, Dellawa forest in Galle district, and Diyadawa forest in Matara district. In selecting the sample, socioeconomic profiles were prepared for 17 Gramasevaka (GS) divisions (lowest administrative unit in Sri Lanka) adjoining the selected forest patches using rapid rural appraisal methods. The total number of forest-dependent households in these GS divisions was identified to be 1,909 in the 17 GS divisions. A sample of 180 forestdependent households $(9.4 \%)$ was selected from the population. The sample was stratified using the GS divisions. The number of households per GS division was determined by considering the proportion of forest-dependent families in the GS division. Random number tables were used to select the 
predetermined number from forest-dependent households of each GS division. Appendix 1 provides the details of the sample distribution.

A member of each household who is mainly responsible for household decisions was interviewed. The survey was conducted in May, July, and August 2000. The questionnaire was pretested and a number of focus group discussions were held before conducting the survey. The information collected included socioeconomic data such as age, education level of the respondent, total household income, number of family members, non-timber forest product extraction during the last year, and the respondent's personal perception of risk for extraction of resources from the natural forest.

People extract different kinds of products from the forest. The NTFP harvesting equation for each product involves a large number of regression equations. Since the households collect different combinations of products, there are no adequate data points to estimate a regression equation for each product. This motivated us to aggregate different NTFP to a single quantity index. The quantity index for collected goods was prepared by using the following formula:

$$
Q_{i}=\frac{\sum_{j=1}^{k} p_{j} \cdot x_{j}}{\bar{p}}, \quad j=1 \ldots . . k
$$

where $Q_{i}$ is the quantity index of NTFP for the ith household and is the average price of the NTFP.

$$
\bar{P}=\frac{\sum_{i=1}^{n} \sum_{j=1}^{k} p_{i j} \cdot x i j}{\sum_{i=1}^{n} \sum_{j=1}^{k} x i j}, i=1 \ldots . . n, j=1 \ldots k
$$

Calculation of the NTFP quantity index requires prices of all the forest species gathered by the villagers. Some NTFPs enter the market exchange process while other NTFPs never enter the market. The latter category is pure subsistence NTFP for which market prices do not exist. The presence of subsistence forest commodities poses a problem in their valuation. This study values NTFP using forest gate prices as the base following Godoy et al., (1993) and Gunatilake et al., (1993). When a product does not have a forest gate price, but does have a price at a nearby town, such prices were used to value NTFP after deducting the cost of transport and opportunity cost of time. If the product is transported manually, only the opportunity cost of time was deducted from the market price. When a product does not have a price both at the village and nearby town, the price of a close substitute was 
used as a proxy. Certain NTFPs have neither prices (in the villages or in nearby towns) nor close substitutes. In such cases, the contingent valuation method was used to value these NTFPs. Only few products fall into this category and an open-ended willingness-to-pay question was asked from randomly selected individuals to find the values.

The level of education of each household was also ranked according to attainment. The lowest rank (1) was for no schooling and the highest rank (7) was for people with university degrees. When the household income data were collected, the annual income of every family member (except separately living members) was included. This comprises agricultural income and nonagricultural income (wage labor, Kithul tapping in nonforest lands, cinnamon bark processing, brick making, carpentry, etc.). Risk perception was measured according to the respondent's answer to the question "How long do you think you can collect NTFPs from the Sinharaja forest?" If the individual feels that he/she can harvest NTFPs for a long period in the future, risk perception was inferred to be low. Risk perception was ranked (1-6) according to the inverse of the length of time period. A market incorporation index was prepared based on the same approach used by Gunatilake (1998) in a previous study. The components of the index are distance to the nearest town; walking distance to get a bus; frequency of bus transport to the village and other facilities available in the village, such as cooperative shop, school, a sub-post office, medical center, and rural bank (see Appendix 2). The information regarding availability of these facilities in each GS division was collected from the Grama Niladhari (Village Headman) of the division.

\section{Results and Discussion}

Out of 180 observations, 175 were included in the analysis. Five observations were excluded from the sample due to inconsistent answers to the IRTP elicitation question. The estimated IRTP values for different time periods are given in Table 3. According to the results, the villagers discount future consumption at an average rate of $24 \%$. This is above the existing market rate of interest for bank loans $(18.5 \%)$. This higher rate can be partly due to the existing poverty of the people engaged in forest products collection. Also, the ranges suggest that under each category of delay in consumption, there is a large variation. As shown in Figure 1, the IRTP values show a clear trend of decline with the increasing delayed time periods. This trend is due to the existence of the common difference effect. Horowitz (1988) and Benzion et al., (1989) have also found a similar pattern of declining IRTP with increasing delayed time periods. 
47

Table 3: $\quad$ Estimated rates of time preference

\begin{tabular}{lcccccc}
\hline & \multicolumn{7}{c}{ Consumption delay (years) } \\
\cline { 2 - 7 } & 1 & 2 & $\mathbf{3}$ & $\mathbf{5}$ & $\mathbf{1 0}$ & $\mathbf{1 5}$ \\
\hline Average & 0.34 & 0.30 & 0.28 & 0.23 & 0.16 & 0.13 \\
Standard & 0.19 & 0.16 & 0.14 & 0.11 & 0.08 & 0.06 \\
deviation & & & & & & \\
Maximum & 0.90 & 0.92 & 0.71 & 0.55 & 0.59 & 0.38 \\
Minimum & 0.03 & 0.03 & 0.03 & 0.00 & 0.00 & 0.00 \\
\hline
\end{tabular}

The behavior of the IRTP over different income groups is also depicted in Figure 1. During the first three years, the highest IRTP values are shown by the second lowest income group (\$520-781), while the highest income group (> \$1,823) holds the lowest IRTP over the years. Generally, the results indicate that IRTP declines when income increases. Every income group behaves almost similarly in valuing future benefits over time when consumption is delayed by different time periods. Further, Figure 1 indicates that the gaps of IRTP among income groups become narrower when the delayed time period increases. The reason for this behavior may be the declining ability to imagine future benefits or costs when they occur in the far distant future (Becker and Mulligan, 1997).

Figure 1: $\quad$ Changes in average IRTP for different income groups

Figure 1

Changes in Average IRTP for Different Income Groups

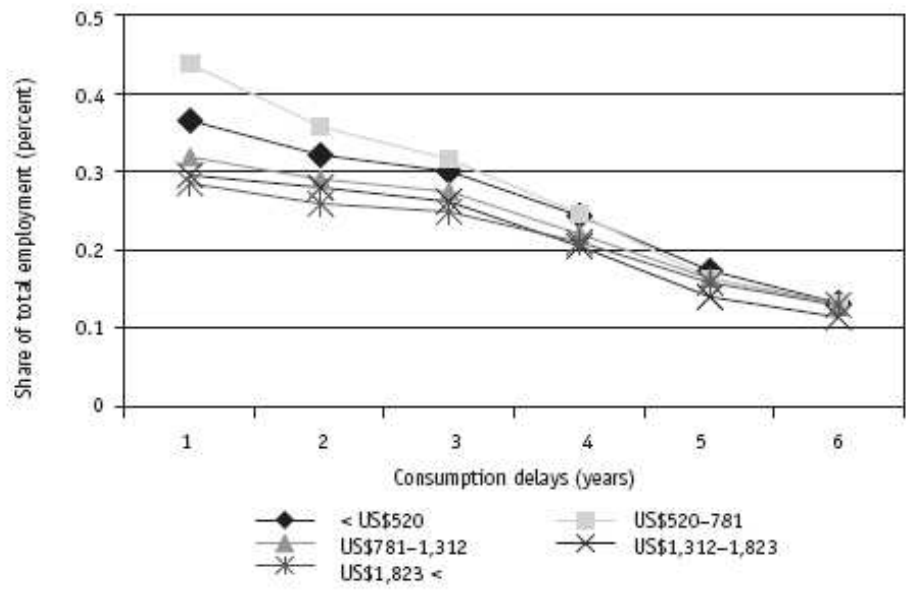

As discussed earlier, the impact of time preference on NTFP extraction was investigated by means of a simultaneous equation model. The descriptive statistics of the variables of these two equations are presented in 
Table 4. IRTP values in the table are the averages of each individual's IRTP over different delayed time periods.

In this study, it was hypothesized that the extent of homestead affects NTFP extraction. Home gardens in the study area, however, do not represent agro-forestry systems as perceived. People in the study area cultivate tea, cinnamon, pepper, coconut, and other perennial agricultural crops mainly as monocultures. In the study area, therefore, homesteads do not produce substitutes for forest products. Because of this reason, the extent of homestead was excluded from the NTFP harvesting model. Correlation matrices obtained from two ordinary least squares regression models were used to check for multicollinearity. The correlation matrices of the variables of the two models presented in Appendix 3 shows that there is no strong correlation among variables. Both equations were specified as log linear models. A number of diagnostic tests indicated the presence of heteroscedasticity. Since the twostage least square procedure does not have the built-in capacity to run for heteroscedastic models, the data were first corrected for heteroscedasticity using the weighted least squares method.

Table 4: Descriptive statistics of the variables used in regression analysis

\begin{tabular}{|c|c|c|c|c|}
\hline Variable & Average & $\begin{array}{l}\text { Standard } \\
\text { deviation }\end{array}$ & Maximum & Minimum \\
\hline $\begin{array}{l}\mathrm{Y}_{2}-\text { Quantity index of NTFP } \\
(\mathrm{kg})\end{array}$ & $4,889.48$ & $6,942.43$ & $37,992.61$ & 88.97 \\
\hline $\mathrm{Y}_{1}-$ Average IRTP & 0.24 & 0.12 & 0.70 & 0.03 \\
\hline $\mathrm{X}_{1}-$ Base value $(\$)$ & 306.00 & 475.00 & $3,125.00$ & 5.00 \\
\hline $\mathrm{X}_{2}-$ Education & 2.55 & 1.03 & 6.00 & 1.00 \\
\hline$X_{3}-$ Total income $(\$)$ & $1,175.00$ & 864.00 & $5,675.0$ & 0.00 \\
\hline $\mathrm{X}_{4}-$ Age of respondent (year) & 45.45 & 11.70 & 87.00 & 18.00 \\
\hline $\mathrm{X}_{5}-$ Risk perception & 3.43 & 1.51 & 6.00 & 1.00 \\
\hline $\mathrm{X}_{6}-$ Agric. Income (\$) & 683.00 & 761.00 & $4,413.00$ & 0.00 \\
\hline $\mathrm{X}_{7}-$ Other income $(\$)$ & 492.00 & 553.00 & $3,250.00$ & 0.00 \\
\hline $\mathrm{X}_{8}-$ Homestead extent (ha) & 0.26 & 0.27 & 1.60 & 0.00 \\
\hline$X_{9}-$ No. of family members & 4.71 & 1.73 & 10.00 & 1.00 \\
\hline $\mathrm{X}_{10}-$ Distance to forest $(\mathrm{km})$ & 0.77 & 0.93 & 4.80 & 0.002 \\
\hline $\mathrm{X}_{11}-$ Male-female ratio & 1.37 & 0.87 & 5.00 & 0.00 \\
\hline $\begin{array}{l}\mathrm{X}_{12}-\text { Market incorporation } \\
\text { index }\end{array}$ & 23.53 & 9.00 & 50.30 & 12.25 \\
\hline
\end{tabular}

NTFP means nontimber forest products

As mentioned earlier, the simultaneity hypothesis was tested using the Hausman test (Greene, 2000). As equations were unidirectional, time preference equation was used to find the estimated residuals and estimated rate of time preference. Then, the ordinary least squares method was used to 
estimate NTFP harvesting after substituting the estimated values in the equation. T-statistics for the estimated residual indicates that the residual is significant at 0.01 level. Thus, the simultaneity assumption was not rejected. Moreover, the models were checked to determine whether their residuals are contemporaneously correlated. For this, the residual of each model was estimated and they were regressed using the ordinary least squares method. The residuals' correlated matrix indicates that errors are not correlated (see Appendix 4). As the residuals of the models are not correlated, models are not contemporaneously correlated in disturbances. Therefore, a seemingly unrelated regression model is not appropriate for this analysis.

The estimated model for determinants of time preference is presented in Table 5. The coefficient of determination $\left(\mathrm{R}^{2}\right)$ of the model is 0.7859 . Adjusted $\mathrm{R}^{2}$ is 0.7828 . The small difference between two $\mathrm{R}^{2}$ values indicates that there are an adequate number of observations in the model given the number of dependent variables. The model explains $78.28 \%$ of the variation of the individual rate of time preference in the peripheral community of the Sinharaja forest.

Table 5: $\quad$ Determinants of IRTP

\begin{tabular}{lcccl}
\hline \multicolumn{1}{c}{ Variable } & Coefficient & $\begin{array}{c}\text { Standard } \\
\text { Error }\end{array}$ & T-ratio & P-value \\
\hline Base value & $-5.87 \mathrm{E}-02$ & $2.11 \mathrm{E}-02$ & -2.775 & $0.006^{* *}$ \\
Education level & $-9.06 \mathrm{E}-02$ & $7.74 \mathrm{E}-02$ & -1.170 & 0.242 \\
Total income & $-2.90 \mathrm{E}-02$ & $1.57 \mathrm{E}-02$ & -1.847 & $0.065^{*}$ \\
Age & -0.22354 & $6.95 \mathrm{E}-02$ & -3.218 & $0.001^{* *}$ \\
Risk perception & 0.21191 & $5.84 \mathrm{E}-02$ & 3.630 & $0.000^{* *}$ \\
Intercept & $-1.76 \mathrm{E}-04$ & $3.12 \mathrm{E}-02$ & $-5.65 \mathrm{E}-03$ & 0.995 \\
\hline
\end{tabular}

The results indicate that the impact of the base value on time preference is negative and statistically significant at 0.05 level. The education-level variable in the estimated model indicates an inverse relationship with rate of time preference as expected. But, it does not show a statistically significant relationship. This result may be due to the inadequate variation of the education variable in the sample. According to the survey results, majority $(53.3 \%)$ of the respondents have attended grades 1 to 5 . About $81.5 \%$ of the respondents belong to three categories (ranks 1, 2, 3) according to the rank assigned for different education levels.

The regression results show that age is positively related to IRTP and it is statistically significant at 0.05 level. Risk perception of individuals shows a positive relationship to IRTP as hypothesized and it is statistically significant at 0.05 level. A noteworthy finding on the determinants of IRTP is the statistically significant negative impact of income. This result reflects that 
the poor individuals have high rate of time preference, confirming previous findings by Hausman (1979), Reddy (1995), and Holden et al., (1998). The overall results of the determinants of IRTP analysis show that our IRTP estimation is reliable; and hence is suitable for examining our main hypothesis - positive relationship between IRTP and rate of NTFP harvesting.

The results of the estimated NTFP extraction model are presented in Table 6. The $\mathrm{R}^{2}$ of this model is 0.8469 . Adjusted $\mathrm{R}^{2}$ is 0.8433 . The two $\mathrm{R}^{2}$ values show a small difference indicating the adequacy of the sample size, given the number of dependent variables. The model explains $84.33 \%$ of variation of the NTFP harvesting by the peripheral community of the Sinharaja forest.

Table 6: $\quad$ Results of NTFP harvesting model

\begin{tabular}{lclll}
\hline \multicolumn{1}{c}{ Variable } & Coefficient & $\begin{array}{c}\text { Standard } \\
\text { Error }\end{array}$ & T-ratio & P-value \\
\hline $\begin{array}{l}\text { Rate of time } \\
\text { preference }\end{array}$ & 2.7121 & 0.590 & 4.597 & $0.000^{* *}$ \\
Education level & $2.65 \mathrm{E}-02$ & 0.297 & $8.94 \mathrm{E}-02$ & 0.929 \\
$\begin{array}{l}\text { Agricultural } \\
\text { income }\end{array}$ & $-2.75 \mathrm{E}-02$ & $3.15 \mathrm{E}-02$ & -0.8747 & 0.382 \\
$\begin{array}{l}\text { Other income } \\
\text { Family size }\end{array}$ & $-7.88 \mathrm{E}-02$ & $2.48 \mathrm{E}-02$ & -3.179 & $0.001^{* *}$ \\
$\begin{array}{l}\text { Distance to forest } \\
\text { Male-female ratio }\end{array}$ & 0.51842 & 0.285 & 1.819 & $0.069^{*}$ \\
Market & -0.14825 & $6.58 \mathrm{E}-02$ & -2.252 & $0.024^{* *}$ \\
incorporation index & 0.38726 & 0.2057 & 1.883 & $0.060^{*}$ \\
Intercept & & 0.2917 & 3.386 & $0.001^{* *}$ \\
\hline & 4.2662 & 0.8838 & 4.827 & $0.000^{* *}$ \\
\hline
\end{tabular}

*Significant at 0.05 level

** Significant at 0.1 level

The most important finding in the NTFP harvesting model is that the rate of time preference positively affects forest resource harvesting. The relationship is statistically significant at 0.05 level. This result agrees with the theoretical expectations regarding time preference and resource extraction. Our finding is, however, different from that of Godoy et al., (1998), owing to different contexts. Our study examines the relationship between IRTP and harvesting nontimber forest products (NTFP) from a protected forest whereas Godoy et al., (1998), focus on forest land clearance. In the case of forest land clearance, impatient individuals clear secondary forests, which does less harm to virgin forests. Godoy et al., (1998), cast doubt on the positive relationship between IRTP and forest resource depletion. Availability of two types of forests for clearance and the differential impacts of clearance of these two types make their case quite different from ours. Therefore, our results do not directly contradict Godoy et al., (1998).'s findings. 
The other results in this model have been shown earlier (see for example, Gunatilake, 1998; Gunatilake and Chakravorty, 2002). Except for a few variables, the results confirm previous findings. Therefore, we briefly discuss the rest of the results of the NTFP harvesting model. Nonagricultural and non-forest income show the expected relationship to NTFP harvesting with statistical significance. Family size and male-female ratio show the expected positive relationship to NTFP harvesting (at 0.1 significance level) as hypothesized. These results indicate that forest extraction activities are male-dominant and larger families extract more NTFP in the study area. Distance to the forest also shows the negative impact on NTFP harvesting as expected.

Education does not show any statistically significant relationship to NTFP harvesting. As mentioned earlier, this result may be due to inadequate variation found in the education variable. Agricultural income also does not show the expected relationship to NTFP harvesting. In this case, the expected negative relationship arises due to competitive time allocation between agriculture and forest resource extraction. However, if forest resource harvesting occurs during the off-season of agriculture, this relationship may not hold. Our data do not show such a pattern of time allocation and hence, this is a matter that needs further investigation. Market incorporation shows a positive relationship to NTFP harvesting. In a previous study, Gunatilake and Gopalakrishnan (2002) show a negative relationship between these variables. Theory tells us that this relationship can be positive or negative. The available empirical evidence is also inconclusive. Therefore, further empirical research on this aspect is warranted.

\section{Conclusions and Policy Implications}

We estimated the IRTP of the peripheral villagers of the Sinharaja Forest Reserve in order to examine the impact of IRTP on NTFP harvesting. A stated preference survey question was used to estimate IRTP and special attention was paid to account for the possible anomalies occurring in such studies. Average IRTP was estimated at $24 \%$, which is higher than the existing market rate of borrowing at the time of investigation. Determinants of the IRTP were assessed using a regression model. Results show that family income and base value are negatively related to IRTP while risk perception and age are positively related to the IRTP. IRTP declines as the time delay in consumption increases for all income groups. This has been observed in many previous researches on IRTP.

The realistic IRTP values and confirmation of their relationships to determinants with theoretical expectations show that our IRTP estimates are reliable. The average IRTP values over different time delays were 
incorporated in the NTFP harvesting model. Results show that people with higher IRTP extract more NTFP. Thus the paper shows that a higher rate of time preference of individuals causes depletion of forest resources.

The paper brings out a number of policy implications. The most significant is the importance of poverty reduction in local communities for effective forest conservation. As discussed earlier, NTFP extraction may become a serious problem in managing protected forests. It is more difficult to find policy tools for managing NTFP harvesting when poor people live near nature reserves and depend on forest resources for livelihood. Under such circumstances, the challenge is to find policy interventions that address both poverty reduction and nature conversation at the same time. Poor individuals have higher discount rates; they do not prefer to wait for long-term benefits of forest conservation. Increasing incomes and enhancing socioeconomic endowments in the short term, preferably through appropriate rural development activities, reduces the direct need to harvest NTFP. In the long run, poverty reduction will have its indirect impact on forest conservation through reduction of IRTP. Therefore, a long-term strategy for nature reserve protection (or conservation management) would require poverty reduction, among other measures.

\section{References}

Anderson, A.B. (1992). Land-Use Strategies for Successful Extractive Economies in Amazonia. In Non-Timber Products from Tropical Forests: Evaluation of a Conservation and Development Strategy, D.C. Nepsted and S. Schwartzman (eds.). New York: The New York Botanical Garden.

Ayres, R.U. and A.V. Kneese (1969). Production, Consumption, and Externalities. The American Economic Review, 59(3):282-297. Available:<http://www.jstor.org/view/00028282/di950411/ 95p06951/0.>

Becker, G.S. and C.B. Mulligan (1970). The Endogenous Determination of Time Preference. Quarterly Journal of Economics, 112(3):729-758.

Benzion, U., A. Rapoport and J. Yagil (1989). Discount Rates Inferred from Decision: An Experimental Study. Management Science, 35:523-539.

Bluffstone, R.A. (1995). The Effect of Labor Market Performance on Deforestation in Developing Countries under Open Access: An Example from Rural Nepal. Journal of Environmental Economics and Management, 29(1):42-63. 
Boardman, A.E., D.H. Greenberg, A.R., Vining and D.L. Weimer (1996). Cost-Benefit Analysis: Concepts and Practices. Upper Saddle River, NJ: Prentice Hall.

Browder, J.O. (1992). Social and Economic Constraints on the Development of Market Oriented Extractive Reserves in Amazon Rainforests. In Non-Timber Forest Products from Tropical Forests: Evaluation of a Conservation and Development Strategy, D. C. Nepsted and S. Schwartzman (eds.). New York: The New York Botanical Garden.

Bulte, E. and D. van Soest (1996). A Note on High Discount Rates and Depletion of Primary Forest. Journal of Agricultural and Resource Economics, 21(2):341-350.

Clark, C.W. (1973). The Economics of Overexploitation. Science, 181:630644.

De Beer, J.H., and M.J. McDermott (1989). The Economic Value of NonTimber Forest Products in Southeast Asia. Netherlands Committee for IUCN, Amsterdam.

Dufoumaud, C.M., J.T. Quinn, H.L. Harrington, C.C. Yu, P. Abeygunawardena and R. Franzosa (1995). A Model of Sustainable Extraction of Non-timber Forest Products in Subsistence. Environment and Planning, 24:1667-1676.

Farzin, Y.H. (1984). The Effect of the Discount Rate on Depletion of Exhaustible Resources. Journal of Political Economics, 92:841-851.

Fisher, A.C. and J.V. Krutilla (1995). Resource Conservation, Environmental Preservation, and the Rate of Discount. In Environmental and Resource Economics (Selected Essays of Anthony C. Fisher). A.C. Fisher (ed.). Cheltenham, Gloucestershire: Edward Elgar Publishing Ltd.

Ghimire, K.B. (1994). Parks and People: Livelihood Issues in National Parks Management in Thailand and Madagascar. Development and Change, 25:195-229.

Godoy, R.A. and S. Bawa (1993). The Economic Value and Sustainable Harvest of Plants and Animals from the Tropical Forest: Assumptions, Hypothesis and Methods. Economic Botany, 47(3):215-219. 
Godoy, R., N. Brokaw and D. Wilkie (1995). The Effect of Income on the Extraction of Non-timber Tropical Forest Products: Model, Hypotheses, and Preliminary Findings from the Sumu Indians of Nicaragua. Human Ecology, 23(1):29-52.

Godoy, R., R. Lubowski and A. Markandya (1993). A Method for the Economic Valuation of Non-timber Tropical Forest Products. Economic Botany, 47:220-233.

Godoy, R., M. Jacobson, J. D. Castro, V. Aliaga, J. Romero and A. Davis (1998). The Role of Tenure Security and Private Time Preference in Neotropical Deforestation. Land Economics, 74(2):162-170.

Gopalakrishnan, C., W.A.R. Wickramasinghe, H.M. Gunatilake and P. Illukpitiya (2005). Estimating the Demand for Non-timber Forest Products among Rural Communities: A Case Study from the Sinharaja Rain Forest Region, Sri Lanka. Agroforestry Systems, 65:13-22.

Greene, W. (2000). Econometric Analysis. 4th ed. New Jersey: Prentice Hall.

Gunatilake, H.M. (1995). An Economic Impact Assessment of the Proposed Conservation Program for Knuckles Forest Range of Sri Lanka on the Peripheral Communities. Journal of Sustainable Forestry, 31(1):114.

Gunatilake, H.M. (1998). The Role of Rural Development in Protecting Tropical Rainforests: Evidence from Sri Lanka. Journal of Environmental Management, 53:273-292.

Gunatilake, H.M. and U. Chakravorty (2002). Forest Protection through Improved Agriculture: A Dynamic Model of Forest Resource Harvesting. Environmental and Resource Economics, 24:1-26.

Gunatilake, H.M. and C. Gopalakrishnan (2002). Time Allocation and Forest Resources Harvesting by Local Communities. Departmental Paper Series, Environmental Economics Unit, Department of Economics, Gothenburg University, Sweden.

Gunatilleke, C.V.S. and I.A.U.N. Gunatilleke (1980). Floristic Composition of Sinharaja: A Rain Forest in Sri Lanka with Special Reference to Endemics. The Sri Lanka Forester, 14:171-179. 
Gunatilake, H.M., A.H. Senaratne and P. Abeygunawardena (1993). Role of Non-Timber Forest Products in the Economy of the Peripheral Communities of Knuckles National Wilderness Area of Sri Lanka: A Farming System Approach. Economic Botany, 47:275-281.

Hanson, J.H. (1992). Extractive Economies in a Historical Perspective: Gum Arabic in West Africa. Advances in Economic Botany, 9:107-114.

Hardin, G. (19680. The Tragedy of the Commons. Science, 162:1243-1248.

Hausman, J.A. (1979). Individual Discount Rates and the Purchase and Utilization of Energy-Using Durables. Bell Journal of Economics, 10(1):33-54.

Holden, S., B. Shiferaw, and M. Wik (1998). Poverty, Market Imperfections and Time Preferences: Of Relevance for Environmental Policy? Environment and Development Economics, 3:105-130.

Homma, A.K.O. (1992). The Dynamics of Extraction in Amazonia: a Historical Perspective. In Non-Timber Products from Tropical Forests: Evaluation of A Conservation and Development Strategy, D.C. Nepsted and S. Schwartzman (eds.). New York: The New York Botanical Garden.

Horowitz, J.K. (1988). Discounting Money Payoffs: An Experimental Analysis. In, Handbook of Behavioral Economics, Vol. 2B, S. Kaish and B. Gilad (eds.). Connecticut: JAI Press.

Hotelling, H. (1931). The Economics of Exhaustible Resources. The Journal of Political Economy, 39(2):137-175.

Kerkvliet, J. and W. Nebesky (1997). Whaling and Wages on Alaska's North Slope: A Time Allocation Approach to Natural Resource Use. Economic Development and Cultural Change, 45(3):651-665.

Loewenstein, G. and D. Prelec (1992). Anomalies in Intertemporal Choice: Evidences and Interpretation. Quarterly Journal of Economics, 107(2):573-597.

McDermott, M., C.V.S. Gunatilleke and I.A.U.N Gunatilleke (1990). The Sinharaja Rain Forest: Conserving Both Biological Diversity and a Way of Life. The Sri Lanka Forester, 16(3\&4):3-22. 
Ministry of Forestry and Environment (1995). Sri Lanka Forestry Sector Master Plan. Forestry Planning Unit, Colombo, Sri Lanka.

Olson, M., and M. Bailey (1981). Positive Time Preference. Journal of Political Economy, 89(1):1-25.

Panayotou, T. (1994). Conservation of Biodiversity and Economic Development: The Concept of Transferable Development Rights. Environmental and Resource Economics, 4:91-110.

Panayotou, T. and P. Ashton (1992). Not by Timber Alone: Economics and Ecology for Sustaining Tropical Forests. Washington D.C: Island Press.

Pender, J.L. (1996). Discount Rates and Credit Markets: Theory and Evidence from Rural India. Journal of Development Economics, 50(2):257296.

Peters, C.M., A.H. Gentry and R.O. Mendelsohn (1989). Valuation of an Amazonian Rainforest. Nature 339:655-656.

Pigou, A.C. (1932). Desires and Satisfactions. In The Economics of Welfare, A. C. Pigou (ed.). London: Macmillan \& Co. Ltd.

Poulos, C. and D. Whittington (2000). Time Preference for Life-Saving Programs: Evidence from Six Less Developed Countries. Environmental Science and Technology, 34(8):1445-1455. Available: <http://www.planning.unc.edu/facstaff/faculty/whittington/Time\%20 Preferences\%20for\%20LifeSaving\%20Programs\%20EST\%202000.pdf.>

Price, C. (1991). Do High Discount Rates Destroy Tropical Forests? Journal of Agricultural Economics, 42(1):77-85.

Reddy, B.S. (1995). Consumer Discount Rates and Energy Carrier Choices in Urban Households. International Journal of Energy Research, 20(4):187-195.

Shyamsundar, P. and R.A. Kramer (1996). Tropical Forest Protection: An Empirical Analysis of the Costs Borne by Local People. Journal of Environmental Economics and Management, 31(2):129-144. 
Simpson, R.D. (1995). Why Integrated Conservation and Development Projects may Achieve Neither Goals. Discussion Paper 95-20, Resources for the Future, Washington D.C.

Stern, N. (2006). The Economics of Climate Change: The Stern Review. Cambridge, UK: Cambridge University Press.

Tisdell, C.A. (1995). Issues in Biodiversity Conservation Including the Role of Local Communities. Environmental Conservation, 22:216-228.

Weitzman, M. (1994). On the Environmental Discount Rate. Journal of Environmental Economics and Management, 26(2):200-209.

Weitzman, M. (1998). Why the Far-Distant Future Should be Discounted at its Lowest Possible Rate. Journal of Environmental Economics and Management, 36(3):201-208.

Wells, M. (1992). Biodiversity Conservation, Affluence and Poverty: Mismatched Costs and Benefits, and Efforts to Remedy Them. Ambio, 21(3):237-243.

World Bank (1993). Strategy for Forest Sector Development in Asia. Technical Paper No. 182, World Bank, Washington D.C.

Zhuang, J., Z. Liang, T. Lin, and F. De Guzman (2007). Theory and Practice in the Choice of Social Discount Rate for Cost-Benefit Analysis: A Survey. ERD Working Paper Series No. 94, Economics and Research Department, Asian Development Bank, Manila. Available: <http://adb.org/Documents/ERD/Working_Papers/WP094.pdf.> 
Appendix 1: Sample distribution

\begin{tabular}{|c|c|c|c|c|}
\hline Forest RESERVE & $\begin{array}{l}\text { GramasevakA } \\
\text { DIVISION }\end{array}$ & $\begin{array}{l}\text { NUMBER of } \\
\text { FAMILIES }\end{array}$ & $\begin{array}{l}\text { NUMBER OF FAMILIES USING } \\
\text { FOREST RESOURCES }\end{array}$ & $\begin{array}{c}\text { NUMBER OF SELECTED } \\
\text { FAMIUIES }\end{array}$ \\
\hline Detwala & Delwala & 1315 & 500 & 47 \\
\hline \multirow[t]{2}{*}{ Walankanda } & Rambuka & 483 & 187 & 18 \\
\hline & Thanabela & 261 & 220 & 21 \\
\hline \multirow[t]{4}{*}{ Runakanda } & Diganna & 216 & 150 & 14 \\
\hline & Thiniyawala & 634 & 75 & 7 \\
\hline & Batagodawila & 275 & 50 & 5 \\
\hline & Kalukandawa & 46 & 40 & 4 \\
\hline \multirow[t]{4}{*}{ Dellawa } & Pahalamillawa & 292 & 25 & 2 \\
\hline & Ihalamillawa & 140 & 35 & 3 \\
\hline & Happitiya & 226 & 95 & 9 \\
\hline & Miyanawatura & 105 & 50 & 5 \\
\hline \multirow[t]{6}{*}{ Diyadawa } & Kotapola-North & 540 & 100 & 9 \\
\hline & Deniyaya-West & 325 & 150 & 14 \\
\hline & Pallegama-South & 538 & 72 & 7 \\
\hline & Pussawela & 268 & 100 & 9 \\
\hline & Deniyaya & 570 & 40 & 4 \\
\hline & Beliattakumbura & 318 & 20 & 2 \\
\hline Total & & & 1909 & 180 \\
\hline
\end{tabular}

Appendix 2: Data used to develop market incorporation index

\begin{tabular}{|c|c|c|c|c|c|c|c|c|}
\hline \multirow[b]{2}{*}{$\begin{array}{l}\text { GRAMASEVAKA } \\
\text { DIVISION }\end{array}$} & \multirow[b]{2}{*}{$\begin{array}{l}\text { DISTANCE } \\
\text { TO NEAREST } \\
\text { TOWN (KM) }\end{array}$} & \multirow{2}{*}{$\begin{array}{l}\text { WALKING } \\
\text { DISTANCE } \\
\text { TO GET A } \\
\text { BUS (KM) }\end{array}$} & \multirow{2}{*}{$\begin{array}{l}\text { FREQUENCY } \\
\text { OF BUS } \\
\text { TRANSPORT } \\
\text { (VISIT/DAY) }\end{array}$} & \multicolumn{5}{|c|}{ OTHER FACILITIES } \\
\hline & & & & $\begin{array}{c}\text { CO- } \\
\text { OPERATIVE } \\
\text { SHOP }\end{array}$ & SCHOOL & $\begin{array}{l}\text { SUB-POST } \\
\text { OFFICE }\end{array}$ & $\begin{array}{c}\text { MEDICAL } \\
\text { CENTER }\end{array}$ & $\begin{array}{l}\text { RuRAL } \\
\text { BANK }\end{array}$ \\
\hline \multicolumn{9}{|l|}{ Delwala FR } \\
\hline Delwala & 12 & 2 & 12 & A & A (13) & A & A & A \\
\hline Uda-delwala & 14 & 2 & 7 & A & A (10) & A & NA & NA \\
\hline \multicolumn{9}{|l|}{ Walankanda FR } \\
\hline Rambukagama & 13 & 0.75 & 20 & A & NA & A & NA & NA \\
\hline Yatantenna & 12.8 & 0.75 & 20 & NA & NA & NA & NA & NA \\
\hline Kajugaswatta & 12.5 & 0.75 & 20 & NA & A (12) & NA & NA & NA \\
\hline Kopikella & 13 & 1.50 & 20 & NA & NA & NA & NA & NA \\
\hline Pandeniya & 12.3 & 0.75 & 20 & NA & A (5) & NA & NA & NA \\
\hline Thanabela & 25 & 3.5 & 20 & NA & A & NA & NA & NA \\
\hline Thebugala & 25 & 1 & 20 & NA & NA & NA & NA & NA \\
\hline \multicolumn{9}{|l|}{ Runakanda FR } \\
\hline Diganna & 11 & 3.5 & 25 & NA & A (5) & NA & NA & NA \\
\hline Thiniyawala & 8 & 2 & 8 & A & A (13) & A & A & NA \\
\hline Batagodawila & 12 & 1.6 & 6 & A & A (11) & NA & NA & NA \\
\hline Kalukandawa & 23 & 6.4 & 6 & NA & NA & NA & NA & NA \\
\hline \multicolumn{9}{|l|}{ Dellawa FR } \\
\hline Ihalamillawa & 8 & 8 & 0 & NA & NA & NA & NA & NA \\
\hline Pahalamillawa & 6 & 6 & 0 & A & A ( (8) & A & NA & NA \\
\hline Happitiya & 7 & 0.5 & 14 & NA & NA & NA & NA & NA \\
\hline Miyanawatyra & 16 & 3 & 14 & NA & NA & NA & NA & NA \\
\hline \multicolumn{9}{|l|}{ Diyadawa FR } \\
\hline Kotapola North & 3 & 0.4 & 100 & A & A (13) & NA & NA & NA \\
\hline Deniyaya West & 1 & 1 & 100 & NA & NA & NA & NA & NA \\
\hline Pallegama South & 4 & 0.8 & 24 & A & NA & NA & NA & NA \\
\hline Pussawela & 8 & 0.5 & 24 & NA & A (10) & NA & NA & NA \\
\hline Deniyaya & 0.25 & 0.25 & 100 & A & A (12) & A & A & A \\
\hline Beliattakumbura & 9 & 1.6 & 24 & NA & NA & A & NA & NA \\
\hline
\end{tabular}

FR means forest reserve; NA means not available: A means available.

Note: Numbers within parenthesis indicate the highest grade available in the school. 
Appendix 3: Tests for multicolinearity

Appendix 4: Test for simultaneity and contemporaneous cross correlation 
APPENDix TABLE 4.1

HAUSMAN TEST RESULtS

\begin{tabular}{|lrrrc|}
\hline Variable & COEfFicient & Standard Error & T-ratio & \multicolumn{1}{c|}{ P-value } \\
Average IRTP & -86728.00000 & 8131.00000 & -10.67 & 0.000 \\
Residual of time preference & 8021.30000 & 787.50000 & 10.19 & 0.000 \\
model & -951.97000 & 149.40000 & -6.37 & 0.000 \\
Education level & -0.01888 & 0.00225 & -8.40 & 0.000 \\
Agricultural income & -0.03547 & 0.00281 & -12.63 & 0.000 \\
Other income & 346.77000 & 86.45000 & 4.01 & 0.000 \\
Number of family members & -716.55000 & 81.39000 & -8.80 & 0.000 \\
Distance to forest & 239.56000 & 119.10000 & 2.01 & 0.044 \\
Male-female ratio & -49.84800 & 8.34400 & -5.97 & 0.000 \\
Index to open market & 31484.00000 & 2585.00000 & 12.18 & 0.000 \\
Constant & & & & \\
\hline
\end{tabular}

IRTP means individual rate of time preference.

APPENDIX TABLE 4.2

Residual Correlation Matrix

\begin{tabular}{|lll|}
\hline E1 & 1 & \\
E2 & $3.78 \mathrm{E}-02$ & 1 \\
& $\mathrm{E} 1$ & $\mathrm{E} 2$ \\
\hline
\end{tabular}

Note: $\mathrm{E} 1$ is the residual of time preference model; E2 is the residual of nontimber forest products model. 